\title{
Evaluation on Indonesian's Local Government Website for Practicing Paradiplomacy
}

\author{
Surwandono \& Ariyanto Nugroho \\ Universitas Muhammadiyah Yogyakarta \\ Muhammad Dedy Yanuar \\ Universitas Veteran Jawa Timur
}

\begin{abstract}
Paradiplomacy as an instrument of local governments to develop international cooperation in the era of industrial revolution 4.0 requires some thoughts and policies relevant to information technology. Website constitutes an important platform for local governments to exercise their Paradiplomacy as a regional practice of conducting international relations. The website becomes a world window for local governments to communicate and cooperate with local government partners and institutions abroad. This article conducts an evaluation study towards local government websites in Indonesia related to the readiness to face the industrial revolution 4.0 in the issue of international cooperation through digital diplomacy means. The preferred research method is to analyze the content of website structure of the Indonesian local government, be it from front-line, content, and/or backline. This article found that the platform of Indonesian local government websites is fairly fragile in the institutionalization of paradiplomacy using website as the instrument. Comprehensive policies from the central and local governments eventually become indispensable in order to make the practice of digital diplomacy by local governments in Indonesia more productive.
\end{abstract}

Keywords: Paradiplomacy, Digital Diplomacy, e-Government

Paradiplomasi sebagai instrumen pemerintah daerah untuk mengembangkan kerja sama internasional di era revolusi industri 4.o memerlukan beberapa pemikiran dan kebijakan yang relevan dengan teknologi informasi. Website merupakan platform penting bagi pemerintah daerah untuk melaksanakan Paradiplomasi mereka sebagai praktik regional dalam melakukan hubungan internasional. Website menjadi jendela dunia bagi pemerintah daerah untuk berkomunikasi dan bekerja sama dengan mitra dan lembaga pemerintah daerah di luar negeri. Artikel ini melakukan kajian evaluasi terhadap website pemerintah daerah di Indonesia terkait kesiapan menghadapi revolusi industri 4.0 dalam isu kerja sama internasional melalui sarana diplomasi digital. Metode penelitian yang dipilih adalah dengan menganalisis isi dari struktur website pemerintah daerah Indonesia, baik dari front-line, content, dan/atau backline. Artikel ini menemukan bahwa platform website pemerintah daerah Indonesia cukup rapuh dalam pelembagaan paradiplomasi dengan menggunakan website sebagai instrumennya. Kebijakan yang komprehensif dari pemerintah pusat dan daerah pada akhirnya menjadi sangat diperlukan agar praktik diplomasi digital oleh pemerintah daerah di Indonesia semakin produktif.

Kata-kata kunci: Paradiplomasi, Diplomasi Digital, e-Government 
"City Diplomacy" as the forerunner of the term Paradiplomacy became well-known after the massive movement of several cities in the United States through UCLG (United Cities and Local Governments) stated that the relationship between local governments in the context of foreign cooperation has obtained official and legal recognition. This cooperation is not designed to diminish the central government's authority in running foreign politics or propaganda to be an independent and sovereign entity within a country Protodiplomacy (Cornago 2018). On the contrary, it originally purposes to assist and contribute to the central authority in developing a country through initiating some potential and strategic cooperation across the border of nationstates. Several regional heads then dared to build associations in the context of local governments' institutionalization of foreign relations. UCLG, which was previously based only on associations between local governments in the United States, inspired the birth of Climate Leadership Group 40 (C40) as a regional head association worldwide (van der Pluijm 2007).

The dynamism of cooperation between local governments has been significantly growing. Cooperation is not limited to the continuous similarities alone, but it is already cross-continuous. The association holds regular meetings of some mayors and governors from several countries around the world. The meeting was conducted regularly, discussing many issues and providing substantive input in the management of international relations today. One of the issues frequently discussed in the $\mathrm{C} 4 \mathrm{O}$ forum is the implementation of leadership governance in this competitive era of globalization and the possibility of reducing the chances of conflict among countries, which was then instituted in the forum C40 in 2005 (Acuto 2013).

Indonesia has 34 provinces, 514 districts, and cities. Sumatra is one of the big islands with the highest number of provinces and districts/cities in Indonesia. Meanwhile, Papua Island, as the largest island in Indonesia, has only two provinces and 42 districts and cities. Details about the number of provinces and districts of the city are reflected in table 1. 


\section{Table 1}

Number of Provinces and Districts/Cities in Indonesia

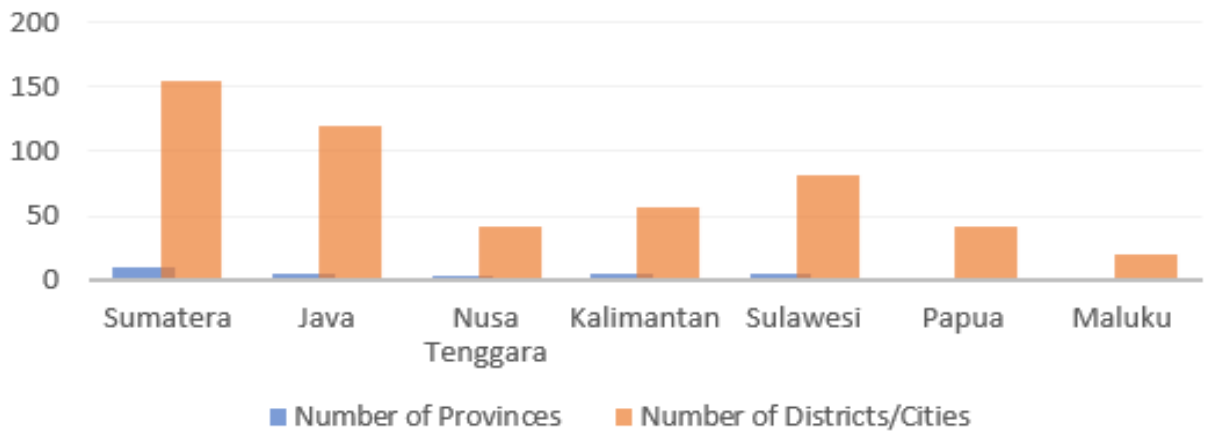

Source: Putri (2020)

Regarding international cooperation, Java island comprising six provinces and 119 districts and cities, is the region with the most international cooperation in Indonesia, in the form of twin city cooperation or twin provinces. The amount of international cooperation by provinces and districts/cities in Java island reached more than 50\% of international cooperation by local governments in Indonesia. Moreover, Jakarta province (one of the provinces in Java Island) has the highest international cooperation in Indonesia, achieving 78 international cooperation (see table 5).

Local governments located on the island of Java tend to develop their areas with the concept of urban community development. According to Zeraoui and Villar (2017) study, they required paradiplomacy as an effective tool to implement it. It is important so that the impact of urban development, which will have implications for several cultural and structural changes, can be carefully mitigated. Paradiplomacy will allow regions to choose their mass partners relevant to the desired urban development design (Zeraoui and Villar 2016). The urban sector contributes to the structure of GDP from the service sector compared to the agricultural and extractive sectors. Therefore, regions with a service economy base urgently need an effective network of cooperation with various parties, both from within and outside the country, to build interdependence. 
Referring to Sergunin and Joenniemi (2014), paradiplomacy is an important element to maintain sustainable development in urbanbased areas. The argument was emphasized by Kania (2019), who stated that paradiplomacy in urban-based areas should prioritize the cooperation agenda to increase economic welfare compared to other agendas, such as political, social, and cultural issues. According to Jesus (2017), paradiplomacy is a form of local government creativity to gain wider social, economic, and political access to solve several regional problems. The central government that wants a better acceleration of development at the regional level inevitably has to provide space for regional governments to explore international cooperation with local governments in other countries with a high potential for cooperation.

Regulation on paradiplomacy in Indonesia has been ruled in detail in the Ministry of Foreign Affairs Regulation No. 3/2019 and the Ministry of Home Affairs No. 25/2020 and generally reviewed in Law No. 23/2014 on Local Government, Law No. 11/2006 on Aceh Government, Law No. 21/2001 on Papua Special Autonomy and changes in Law No. 35/2008 on Changes in Special Autonomy of West Papua, and Law No. 13/2012 on Yogyakarta (Surwandono and Maksum 2020). The term paradiplomacy, however, is not introduced in the regulation since the government of Indonesia preferred international cooperation by local governments as the chosen diction.

This article focuses more on the study of paradiplomacy attributed to the challenges of the industrial revolution 4.0 as Adiwibowo and Putri (2016) once did. The study of paradiplomacy in Indonesia, so far, has been more about the advantages gained by a region when conducting international cooperation (Damayanti 2012), including the study of effectiveness, opportunities, roles, and obstacles experienced by several local governments (Bakov and Kerimov 2018). This article will fill the gap of argument, in which paradiplomacy discussions are often assumed to be elitist, procedural, and even artificial.

Even in the media's timeline, international cooperation initiatives by local governments (Stremoukhov 2019 \& 2021) are frequently understood as unpopular and inefficient policies and not pro to the public. Comparative visits and studies abroad for cooperation are frequently considered minor and inefficient. The public only looks at travel activities and does not get detailed information about the impact of paradiplomacy policies on economic and social welfare 
in society (Surwandono 2019).

This article will encourage the practice of paradiplomacy by using the internet, where visiting and promoting cooperation uses more cyberspace than physical activity. As a result, the assumption of paradiplomacy as a traveling activity among some public officials, which has been viewed as minor by the public, can be eliminated. The practice of paradiplomacy by using the internet will be an efficient platform for both the interests of local governments, the public interest, and the national interest. An important question in this article is how to institutionalize local governments in carrying out Paradiplomacy practices using internet diplomacy; have the local governments systematically institutionalized paradiplomacy internet diplomacy to exercise practical diplomacy? or are they still running it artificially?

\section{Paradiplomacy: Concept and Practice}

According to Mukti et al. (2019), the term Paradiplomacy was first introduced in the academic debate by a Basque scientist, Panayotis Soldatos, in the 1980 . The diction, paradiplomacy, was chosen as an alternative to the term Parallel Diplomacy, which refers to "the foreign policy of non-central governments". Panayotis Soldatos takes the template of foreign relations practices conducted by regional governments in Spain with several regional authorities in Latin America, wherein the historical context of both has a strong emotional connection (Mukti et al. 2019).

Meanwhile, Ivo Duchacek proposed the term to describe relations between local governments in an international cooperation forum with the concept of "micro-diplomacy" (Mukti 2015) in his book entitled "Perforated Sovereignties Towards a Typology of New Actors in International Relations", especially in the chapter "Federalism and International Relations: The Role of Sub-national Units". The term micro-diplomacy is defined as diplomacy between a sub-national government in a country and another sub-national government in a different country, without any boundaries among those countries.

In the article Paradiplomacy and Regional Networking, Michael Keating defined Paradiplomacy as regional diplomacy under the sovereignty of a country whose mechanism makes the state actor 
a liaison to the creation of the relationship. The most recent definition of paradiplomacy, which Kuznetsov defined, is looking at the dimensions of foreign relations by the local government in 10 dimensions of paradiplomacy (Keating 2000). Based on his viewpoints, not all foreign relations practices by local governments can be interpreted as Paradiplomacy. Paradiplomacy symptoms are often referred to as elitist symptoms rather than institutional symptoms (Kuznetsov 2014). Accordingly, Paradiplomacy can be expressed as a formal and institutional activity because such cooperation has been known and obtained approval from the central government.

Then the question is, what drives local governments willing to conduct international relations? Adiwibowo and Putri, citing Ravenheill's view, expressed that the motive of Paradiplomacy is an attempt by the local government to gain broader access in terms of improving regional welfare under the supervision of the central government in order to deal with globalization (Adibowo and Putri 2016). Therefore, it means that the region's main motivation to conduct paradiplomacy activities is economic factors. The regional objective of paradiplomacy, in this case, is to attract foreign investment, bring multinational companies to their territory, and target new export markets (Keating, 1999). However, it does not close the possibility that the motives of the Paradiplomacy are also for political interests in secession, as happened in Quebec or Catalonia (Lecours 2008).

How to build effectiveand productiveparadiplomacy? Duran's study in paradiplomacy highlighted the elements of the communication process. Building the institutionalization of paradiplomacy without institutionalizing the communication system will be contra-productive (Cyrill and Pasha 2019). Institutionalized communication through communicative and accessible media will reduce the possibility of distortion (Duran 2015). In this context, communication media are very relevant in the institutionalization of paradiplomacy during the Covid-19 pandemic. It is apparent in the new regulations amid the pandemic era, such as the policy for eliminating the Covid-19 virus by social distancing and conducting paradiplomacy online.

An important element in communication using online media is the use of language that partners easily understand. Akimov's study showed that several countries use international languages as an effort to strengthen paradiplomacy interactions. For example, the 
Canadian state of Quebec uses French to establish a network of cooperation with some countries that use French as the language of instruction (Akimov 2018). In addition, local government websites with a robust paradiplomacy cooperation network tended to design language into a bilingual or multilingual system (Criekemans 2010).

How to build paradiplomacy in a pandemic era? So far, there is a prominent view that the effort to start paradiplomacy cooperation is by conducting direct visits to explore, negotiate, and finalize cooperation. However, building understanding between local governments cannot be done without going through physical activity. A study conducted by Stremoukhov showed that the practice of paradiplomacy is primarily determined by how often governors or regional heads travel abroad to build international cooperation (Stremoukhov 2019). Paradiplomacy tends to be very elitist, where the creativity and vision of the regional head will play an essential role in initiating and mobilizing foreign cooperation. It becomes problematic if the leadership transition in the local government does not get a leader who has a personal vision to carry out international cooperation.

Smith has an advanced idea on paradiplomacy that it should be based on the creativity and visibility of regional leaders and must be institutionalized within the local government structure. Local governments must build internal and external networks to support the effectiveness of paradiplomacy. External networks, such as joining city government associations, will simultaneously expand the interaction process (Smith 2019). The establishment of the local governments' association allows them to have access to communicate regularly and transparently. The association will provide access to information on the dynamics of the development of city governments globally, and the members of the association can interact with each other, both bilaterally and multilaterally.

Meanwhile, the internal network is built by infrastructure within the local government, namely a paradiplomacy information system, which is institutionalized in the local government website (Koffa and Kastania 2010). The website will be a gate for local governments to interact with paradiplomacy stakeholders (Cha et al. 2015). According to Bai et al. (2020), the website's effectiveness is primarily determined by its ability to provide access for the parties who utilize the available information structure. Therefore, the more local government websites provide broad access to 
stakeholders, the smoother information traffic will be, and the better its functionality will be (Bai et al. 2020).

To evaluate the practice of paradiplomacy by using the website of local governments in Indonesia, the author chose to use content analysis to understand the structure of Indonesia's policy regarding institutional website governance and measure the performance of local government websites. The steps taken are as follows: First, we conduct a content analysis of the policy structure of diplomacy in the context of international cooperation by the region, referring to the regulation of Ministry of Foreign Affairs No. 3/2019 and the regulation of Ministry of Home Affairs No. 25 of 2020. Second, we conduct a content analysis on local government websites, especially in Java, considering the tremendous amount of international cooperation compared to local governments outside Java by using website performance as measuring tools in the form of frontline, content, and backline. Third, we compare local government websites in Indonesia with several cities in Asia to get an accurate picture of the institutionalization of local government websites abroad to build international cooperation.

\section{E-Government and Paradiplomacy in Indonesia}

The idea of building a digital infra-structure of local government has become an important trend in the last 20 years as an effort to provide services that are fast, transparent, and easily accessible to the public. A number of local governments at the provincial level, such as the Local Government of DKI Jakarta, West Java, Central Java, East Java and Yogyakarta have begun to build smart city as a model of improving plenary services for modern people who want speed and transparency as part of the vision of building e-government in early 2010 (Martinez and Masron 2020). A number of district and city governments, such as Surabaya, Bandung, Yogyakarta have also built smart city concepts. Even Bolaang Mangondow regency, a district in Central Sulawesi and several districts/cities in the border area, are also interested in developing smart city as part of a big concept about e-government (Budi et al. 2020).

The smart city idea also facilitated the paradiplomacy space for the local governments in conducting international cooperation productively and effectively. With regards to the regulation of 
the Ministry of Home Affairs No. 25/2020, the drafting of the cooperation plan is determined by the activity of the study using information technology tools, which then being verified through various visitations and/or inviting potential partners. The use of information technology has become a necessity in today's governance, which became popularly known as the so-called e-government.

Anumber oflocalgovernments haveimplemented governanceusing e-government tools. However, the governance of e-government tends to be inward looking still, where e-government is more for domestic needs services instead of the needs of the international public, such as tax services in the Tax office, copyright registration services at the Law and Human Rights office, Passport and Visa services in Immigration, e-procurement services, residential registration services in the Civil office as well as governance on program transparency and the use of program budgets in a number of local governments (Jauhari et al. 2020).

Well, the question is how about the outward e-government looking (Warf 2013) ? Outward looking e-government services place public services globally, where the public is not only defined as the affairs of individuals, groups, or domestic corporations per se, but much more broadly. In an increasingly information-connected world, government websites functioning as public servants should extend its range to be more globally. The public service also uses benchmarking of international services, in this case referring to a number of international conventions that have been ratified by the government. Service standards using SNI should be converted into international standards so that spaces of government service can be easily accessed by the wider public and community. The website is a miniature of a compact and informative governance to attract anyone to visit. Artificial intelligence advances are able to read information posted in cyberspace quickly using search engines (Wang and Wang 2013).

How do we make e-government modern and global? First, the design of the language used. Language will give the public space to communicate smoothly and effectively (Segovia et al. 2009) which means that the government website must start transforming by using at least two languages, namely national language and international language. The addition of international language feature will allow information on the website to be accessible by the international public, be it individuals, social institutions, 
government and/or non-governmental institutions.

A number of websites in overseas provinces such as Hiroshima, Dubai, Liverpool, Beijing, Manila, Bangkok, Selangor, design themselves as a global website equipped with the option of multiple languages. Hiroshima offers up to 6 language options on its local government website. Similarly, Dubai as a country situated in the Middle East region also offers 4 choices of languages (Bedoya et al. 2018). Selangor, as one of the states in Malaysia, provides two language facilities, namely Malay and English (Yinqi 2011).

Several examples of provinces above are actually provinces with very high regional welfare indexes (IPM), above 15. Meanwhile, Indonesia's average IPM index is only at 7.2. Yet, the province views that grant broader access through language will improve the welfare index, linked to the growing number of people visiting, shopping, or even investing, either from home or even abroad. What about Indonesia? Referencing the study from Yunita and Aprianto (2018) on the governance of e-government in Indonesia still shows unsatisfactory results. Only 4 regions, of which the local government website have been designed for extensive benefits. Additionally, Firdaus' findings which measure the performance of local government websites using databases from the Ministry of Home Affairs showed that the average of Page Speed Grade is $59 \%$ or in grade E. Meaning that the quality of local government websites based on google-generated index is still utterly low (Masyhur 2014) .

Even in general size the performance of the website is still not optimal, then what about stepping in the context towards global e-government? A number of local government websites unfortunately do not present more than one language choice. Even DKI Jakarta, as the capital of the country and the epicenter of international cooperation in Indonesia, does not provide access to foreign languages. The municipality of Bogor, a city awarded with the first rank of best websites in Indonesia, also does not provide international language options (Surwandono et al. 2020) .

Those two local governments, which are construed as the benchmark of good website in Indonesia, have not provided such access. Is it a prohibition to grant an access of international language? Per the regulation of the Ministry of Communication and Information, there is no prohibition on the use of foreign languages on government websites, as long as there is still the 
use of Indonesian as the main language. The Draft of the Ministry of Communication and Information on the implementation of portals and websites of government agencies, which have been drafted since 2017, has not been published until now, stating that the use of foreign languages is only placed as an option, and is not a liability. This needs to be further explored as to why local governments in Indonesia do not provide access to international languages on the website, while the Ministry of Communication and Information No. 25 of 2020 provides a wide opportunity in the process of exploring cooperation that entails the use of information technology.

Obviously, these policy choices would be counterproductive in the context of granting greater access to users, especially foreigners, foreign institutions or even local governments abroad. Consequently, it is predictable that visitors from the web can be as certain as the large domestic population. This is reflected in public voice features, reports and the like. Its correspondence conducted by locals.

Unfortunately, the visitor matrix feature does not much provide infographic. Only Banten government provides infographics on daily basis, not based on the origin of the parties who visit the website. The lack of access to international language will have a profound effect on potential promotion capabilities of the region in the context of international cooperation. Websites that are able to provide massive connections have not been widely used by local governments to build further communication with potential partners abroad. In the context of Paradiplomacy, the government should encourage the obligatory use of bilingual language on the government websites, namely in Bahasa Indonesia and English. All capital cities in ASEAN countries like Selangor, Bangkok, Manila, Singapore, Hanoi, Bandar Seri Begawan, have long used a two-language usage policy on its website (Iamamphai et al. 2016).

The government, through the regulation of Ministry of Communication and Information, can make revisions related to the use of foreign languages as one of the defining indicators in awarding to quality websites, as well as mandatory requirements of a local government web (Martani et al. 2014). The Corruption Eradication Commission (KPK) website, regarded as the best website in the category of government institution, also does not use two languages. KPK website was selected as the best web due to the aspect of transparency, and the interaction of complaint 
services is considered fast and informative. Similarly, the best local government website, Bogor city, has also not given access to the use of international languages on its website.

Second, the additional feature about the potentials of the area, which is in line with the goal of international cooperation to promote regional potential. The feature structure in the government website has been so far more patterned with formal and normative legal information, such as organizational structure, services, regulatory downloads, and news posts. There is no denying that the structure of local government websites is affected by the regulation of Ministry of Communication and Information. The regulation of Ministry of Communication and Information regulations of 2007 and 2016, which require a number of features such as homepages, organizational structures and reader letters (Kurniawan et al.2017). This template is a mandatory requirement in every government website procurement. Even massive web standards are normative and technical, and have not talked much about the substantial and promotional aspects, such as addition of standards about national identity, management, content, typography, navigation, technology and information security (Amalia et al. 2017). The portal of the web must also contain a number of elements such as the profile of the governing body; a single narrative related to government priority policies and programs at the direction of the president; excellent public services to government bodies; policies and legal products of government agencies; implementation of programs and activities of government agencies; aspirational and complaints services; website contacts.

Referring to the Guidebook of Local Government Website Implementation - Depkominfo, 2003, quoted by Wiratmo et al. (2017) ( the website which is effective in building public communication contains at least some of the following elements. First, functionality, accessibility, usability. This means that the website can perform functions well if the website provides extensive access for users to take advantage of it easily. Second, cooperation. Local government websites should offer the idea of cooperation for all parties. Openness to cooperation opportunities shows that the website is in order to build communication effectively. Third, effective content. The preparation of information should be prepared with the use of informative and straightforward word diction so as not to cause misinterpretation of the information submitted. Fourth, two-way communication. when two-way communication has been 
well established, it means that it already provided a feature that lets users ask questions and then get a formal response from the government. Fifth, evaluate success. This means that the website provides information that can be used by the website manager to find out how far the information provided in the website is useful, including the information of visits from users. Sixth, the accessibility of finding sites. The website manager should be able to manage in the search engine, in which the website address can be accessed on the first page of the search engine. There is also a news search feature on the website page. Seventh, well arranged service. As an official website, it ought to use news sources from accountable reference sources.

In a simpler context, the website can actually be rated productivity in two major categories: first, the initial view (front-line or office-line). The initial view instantly shows whether the website design will be informative, having extensive access, open cooperation offers or other features. Second, the content of the information offered by the website. The content of the website will provide information to the user, whether updating the website information running or not. Including what types of information are updated regularly.

\section{Picture 1}

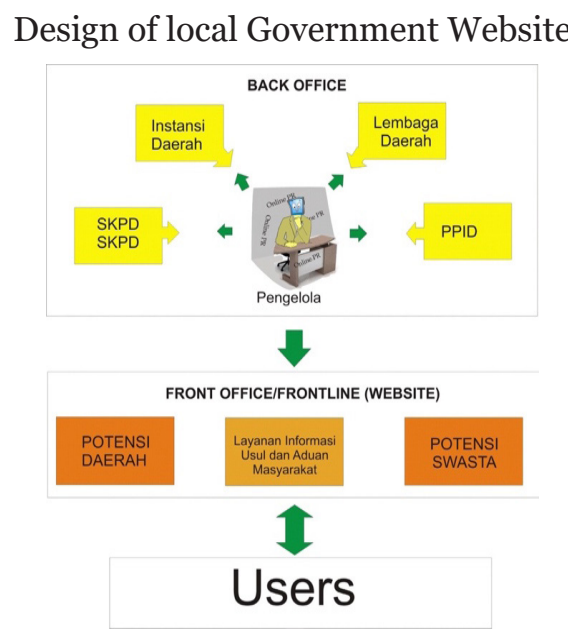

Sources: Wiratmo et al. (2017)

The aforementioned image of local government website design and the importance of front-line management, i.e., has been composed in the website itself. The better the features, the more the outer 
packaging of the website has been productive. However, it also depends on the back-office institutional structure that will respond to interactions within the website with updated and informative information content. Adaptive and professional bureaucratic capabilities in supporting website productivity have also been considerably determining the success of the website in promoting the potential of the region.

Table 2

Frontline Local Government Website in using foreign language

\begin{tabular}{|c|l|c|c|}
\hline No & \multicolumn{1}{|c|}{ Website } & Level & $\begin{array}{c}\text { Foreign } \\
\text { Language }\end{array}$ \\
\hline 1 & Jakarta & Province & None \\
\hline 2 & Central Java & Province & None \\
\hline 3 & West Java & Province & None \\
\hline 4 & East Java & Province & None \\
\hline 5 & Bogor & City & None \\
\hline 6 & Surabaya & City & None \\
\hline 7 & Yogyakarta & City & None \\
\hline
\end{tabular}

Source: Surwandono et al. (2020)

The table describes frontlines of a number of local government websites at the provincial and city level in Java (minus Banten Province). Three cities were selected related to their respective quality, Bogor as the best website in Indonesia 2017, while Surabaya was chosen in relation to the amount of international cooperation conducted, as well as the city of Yogyakarta was also chosen related to the large number of international cooperation. From the 7 provincial and city websites that are advanced in the development of communication infrastructure, it turns out that the website is still very minimalist in the context of providing extensive access for users, since the websites do not provide access to the use of international languages despite providing lots of content (Surwandono et al. 2020). 
Table 3

Frontline Local Government Website in providing opportunities for cooperation

\begin{tabular}{|c|l|c|c|}
\hline No & Website & $\begin{array}{c}\text { Social and Economic } \\
\text { Capital Features }\end{array}$ & $\begin{array}{c}\text { Cooperation } \\
\text { Feature }\end{array}$ \\
\hline 1 & Jakarta & Available & None \\
\hline 2 & Central Java & Available & None \\
\hline 3 & West Java & Available & None \\
\hline 4 & East Java & Available & None \\
\hline 5 & Bogor & Available & None \\
\hline 6 & Surabaya & Available & None \\
\hline 7 & Yogyakarta & Available & None \\
\hline
\end{tabular}

Source: (Surwandono et al. 2020)

The table above shows that frontline local government websites have not yet articulated ideas around Paradiplomacy. Information about the potential of the area is indeed available, but the general information is not enough to attract interest and curiosity of public users. The information provided is often at a glance level, so information tends to be very general. Moreover, there are no features in frontline about cooperation, either with domestic or international partners. Variable cooperation seemed not regarded as an important variable in the creation of local government websites.

Comparing to the website of the city of Dubai in Qatar, where in its frontline it is instantly given a straightforward tagline about the offer of cooperation. Dubai is a highly developed city in infrastructure and economic growth, still seeing it as important that the necessity of cooperation should be regarded as an important part in building people's well-being (Giampiccoli and Mtapuri 2017).

Table 4

Frontline Local Government Website in building interaction with users

\begin{tabular}{|c|l|c|c|}
\hline No & Website & User Information & User From \\
\hline 1 & Jakarta & Available & Unavailable \\
\hline 2 & Central Java & Available & Unavailable \\
\hline 3 & West Java & Available & Unavailable \\
\hline 4 & East Java & Available & Unavailable \\
\hline
\end{tabular}


Evaluation on Indonesian's Local Government Website for Practicing Paradiplomacy

\begin{tabular}{|c|l|l|c|}
\hline 5 & Bogor & Available & Unavailable \\
\hline 6 & Surabaya & Available & Unavailable \\
\hline 7 & Yogyakarta & Available & Unavailable \\
\hline
\end{tabular}

Source: Surwandono and Maksum (2020)

The table above shows that the development of information governance that enables systematic evaluation of website use is not reflected. How to track the level of visits, when the visit data is not easily accessible, either by the manager or the users. Providing user features is actually very easy in the website design (Surwandono and Maksum 2020). The big question is, why has this simple front-line not well managed? What is the pull of interest? Why do almost all local government websites not provide this information?

\section{Table 5}

News Content related to Paradiplomacy in Local Government Website

\begin{tabular}{|c|c|c|c|c|c|c|}
\hline \multirow[b]{2}{*}{ No } & \multirow[b]{2}{*}{ Website } & \multirow{2}{*}{$\begin{array}{c}\text { Para- } \\
\text { diplomacy } \\
\text { Agreement* }\end{array}$} & \multicolumn{4}{|c|}{ Word Represent Paradiplomacy Dimensions } \\
\hline & & & $\begin{array}{c}\text { Sister } \\
\text { Province }^{* *}\end{array}$ & Sister City ${ }^{* *}$ & Foreign ${ }^{* *}$ & $\begin{array}{l}\text { International } \\
\text { Cooperation }^{* *}\end{array}$ \\
\hline 1 & Jakarta & 78 & $\mathrm{O}$ & 9 & 10 & 10 \\
\hline 2 & West Java & 26 & 9 & $\mathrm{O}$ & 21 & 6 \\
\hline 3 & East Java & 20 & $\mathrm{O}$ & 1 & 10 & o \\
\hline 4 & Yogyakarta & 14 & 17 & 13 & 176 & 7 \\
\hline 5 & Central Java & 8 & 6 & 4 & $345^{*}$ & 45 \\
\hline
\end{tabular}

Source: Surwandono et al. (2O2O)

DKI Jakarta is the province that has the most sister city and sister province cooperation in Indonesia. The number of international cooperation of the regional government of DKI Jakarta reached 78 , which means $1 / 3$ of the total amount of foreign cooperation by the local government in Indonesia is carried out by the Government of DKI Jakarta. However, it is interesting that DKI Jakarta does not display much information about the cooperation. There are only nine news stories that inform the dynamics of foreign cooperation of the Jakarta local government. 
In this context it can be understood that the Jakarta city government has not provided an adequate portion of the performance of Paradiplomacy activities. In a simple context, if there are 78 foreign cooperation by the local government, if once a year there is adequate activity, there are already 78 news stories about the performance of Paradiplomacy. The tracking of sister city, which was only found nine times, shows that the cooperation of the local government has not been an important news option. Is it true? It hence does need further investigation (Surwandono et al. 2020).

West Java is a very large province, and has the largest district/ city in Java. The population of West Java is also the province with the highest population. What is the case with information related to Paradiplomacy performance? West Java has a total of 26 international cooperation. But there are only 9 news stories about sister province. And there is no news about sister city, while the number of sister city in west Java regional government is relatively large. What does that mean? Is information about Paradiplomacy as information less useful to the public so that the portion of the news is very lacking? This trend needs to be further tracked in the Paradiplomacy news structure on local government websites.

Similarly, East Java, a vast province with the second largest population in Java. East Java has 20 cooperation with local governments abroad, not doing any news at all in the last 3 years related to sister province. And there's only one news story about sister city. What does it mean? It's whether cooperation only stays in documents, or the result of cooperation does not have high news so it does not need to be officially reported on the website of the local government. It is a question that needs to be taken seriously.

Yogyakarta Special Region province is the smallest province in Java island. However, the province has an advantage in the management of Paradiplomacy compared to the major provinces in Indonesia. Yogyakarta as the most productive province has been providing more information on the realization of foreign cooperation by local governments. Yogyakarta province has 14 cooperation with foreign countries, dissemination of the cooperation information on its website is quite productive, where the total amount of news about sister city and sister province reaches up to 30 times. This is the highest news number amongst the 5 provinces in Java.

This fact shows that local governments view foreign cooperation as a substantial activity, and not a ceremonial activity. In many 
people's views on the mass media line, visitation activities and comparative studies for foreign cooperation, it is still frequently perceived as an unproductive activity (Maksum and Surwandono 2019). Instead, the Government of Yogyakarta showed that the international cooperation has shown adequate performance which led to the productive improvement for the sake of the community welfare.

Central Java province is the province that has the least foreign cooperation compared to the other provinces in Java, where the number of cooperation has as much as 8 cooperation. Although the amount of cooperation is not that much, Central Java has been actively involved in implementing Paradiplomacy, where there is news about sister city and sister province as many as 10 times. Upon comparation in the context of the percentage of news and cooperation documents owned, Central Java province is already higher than DKI Jakarta, West Java and East Java.

In the content of foreign word usage and international cooperation, Central Java became the province that used the most words related to Paradiplomacy activities. The word foreign and international cooperation is used more than 350 times. It means that there is actually a big idea that the Central Java government sees the importance of international cooperation by the government as an effort to improve the welfare of the people. Only at the formalization level of international cooperation, the idea has not been materialized in formal legal documents.

\section{Conclusion}

Paradiplomacy in the era of industrial revolution 4.0 entails supra-structure and infra-structure digital diplomacy. The institutionalization of digital diplomacy by local governments is supposed to be managed systematically and comprehensively. The local government website as the frontline image of local government should be seriously designed to display the effect of high attraction power to the audience both at the national and international level. This is where the importance of digital infra-structure diplomacy is modern and visionary. The structure of the news on the website should display a variety and a wide range of information. Human resources are necessary to convey information with attractive packaging and with language options that are easy for all 
stakeholders to understand. Here is where the importance of intelligent and creative ideas from Paradiplomacy policy managers constitutes as part of the supra-structure policy. This article has eventually found a constructive insight towards the importance of strengthening infrastructure and the supra-structure of digital diplomacy in order to support effective and productive Paradiplomacy practices.

\section{Acknowledgement:}

We would like to thank the Indonesian Higher Education Directorate (RISTEK DIKTI) for funding this research and the anonymous reviewers for their useful comments. The views expressed in this article are our own and do not represent RISTEK DIKTI.

\section{References}

\section{Books and Book Chapters}

Cornago, Noe, 2018. "Paradiplomacy and Protodiplomacy", in Gordon Martel (ed.), 2018. The Encyclopedia of Diplomacy. Chichester: Wiley Blackwell

Criekemans, David, 2010. "Regional sub-State diplomacy from a comparative perspective: Quebec, Scotland, Bavaria, Catalonia, Wallonia and Flanders", in David Criekemans (ed.), 2010. Regional Sub-State Diplomacy Today. Leiden: Martinus Nijhoff Publishers.

Duran, Manuel, 2015. "Paradiplomacy as Communication", in Mediterranean Paradiplomacies: The Dynamics of Diplomatic Reterritorialization. Leiden: Brill.

Kuznetsov, Alexander, 2014. "Theory and Practice of Paradiplomacy", in Theory and practice of paradiplomacy: subnational governments in international affairs. London: Routledge.

Smith, Heidi Jane M., 2019. "City Networks and Paradiplomacy 
Evaluation on Indonesian's Local Government Website for Practicing Paradiplomacy

as Global Public Policy", in Diane Stone and Kim Moloney (eds.), 2019. The Oxford Handbook of Global Policy and Transnational Administration, pp.129-47. Oxford: Oxford University Press.

Surwandono, S., et al., 2020. Pelembagaan Kebijakan Paradiplomasi di Indonesia. Yogyakarta: LP3M UMY.

Warf, B., 2013. "Global E-Government”, in Global Geographies of the Internet (pp. 115-138). Dordrecht: Springer.

\section{Journal and Online Journal}

Acuto, Michele, 2013. “The new climate leaders?”, Review of International Studies, 39 (4): 835-857.

Adibowo, Rino, and Sylvia Octa Putri, 2016. "Penerapan E-Government Dalam Paradiplomasi Pemerintah Kota Bandung”, Jurnal Ilmu Politik dan Komunikasi, VI (2): 91-100.

Akimov, Y.G., 2018. "Linguistic Dimension of Quebec Paradiplomacy", RSUH/RGGU Bulletin Series: Political Science, History, International Relations, 2018 (3): 7-25.

Bai, Y., et al., 2020. "Accessibility of local government websites: influence of financial resources, county characteristics and local demographics", Universal Access in the Information Society, 1-11.

Bakov, Anton, and Aleksandr Kerimov, 2018. "Regions in International Activity: Factors of Development of the Paradiplomacy", Discourse, 32-33 (3-4): 164-172.

Bedoya, J.C.M., et al., 2018. "Paradiplomacia de Dubái (Dubai’s paradiplomacy)”, Espacios, 39 (16): 16-27.

Budi, N.F.A., et al., 2020. "A study of government 2.0 implementation in Indonesia", Socio-Economic Planning Sciences, 72 (2020): 1-10.

Cha, Heewon, et al., 2015. "Exploring websites of foreign embassies as a dialogue space for diplomatic offices and foreign 
publics: Based on dialogic theory of public relations", International Journal of Multimedia and Ubiquitous Engineering, 10 (2): 297-308.

Damayanti, Christy, 2012. "Potensi Paradiplomasi dalam Mendukung Kinerja Diplomasi Indonesia Menuju Komunitas ASEAN", Transformasi, 14 (22): 1-9.

Giampiccoli, Andrea, and Oliver Mtapuri, 2017. “Abu Dhabi, Doha and Dubai: Going online-a Comparative Analysis of their Visibility on a Booking Website", The Arab World Geographer, 20 (4): 282-302.

Jauhari, Arief, et al., 2020. "Are E-Government and Bureaucratic Reform Promoting Good Governance towards a Better Performance of Public Organization?”, Quality-Access to Success, 21 (175): 25-30.

Kania, Magdalena, 2019. "Beyond the Economic Agenda: Towards a Normative Dimension of Paradiplomacy", Politicke vedy. 22 (2): 61-77.

Keating, Michael, 1999. "Regions and international affairs: motives, opportunities and strategies", Regional \& Federal Studies, 9(1): 1-16.

Kurniawan, F., et al., 2017. "Indonesia local government information completeness on the web", Procedia Computer Science, 124: 21-28.

Maksum, Ali, and S. Surwandono, 2019. "The Dynamics of Paradiplomacy Practices in the 'Frontier' Areas in Indonesia”, Journal of ASEAN Studies, 6 (2): 137-154.

Martani, D., et al., 2014. "Disclosure of non-financial information about public services on the official website of local governments in Indonesia”, Journal of Theoretical and Applied Information Technology, 66 (2): 500-512.

Martinez, Rafael, and Irna Nurlina Masron, 2020. "Jakarta: A city of cities", Cities, 106 (102868): 1-11.

Masyhur, Firdaus, 2014. "Kinerja Website Resmi Pemerintah Provinsi di Indonesia”, Jurnal Pekommas, 17 (1): 9-14. 
Evaluation on Indonesian's Local Government Website for Practicing Paradiplomacy

Mukti, T.A., et al., 2019. "Paradiplomacy Management and Local Political Movement in Aceh, Indonesia, and Catalonia, Spain”, European Journal of East Asian Studies, 18 (1): 66-92.

Mukti, Takdir A., 2015. "Paradiplomacy: Bangkitnya Aktor Lokal di Fora Internasional", The Politics: Jurnal Magister Ilmu Politik Universitas Hasanudin, 1 (1): 85-94.

Segovia, R.H., et al., 2009. "Paralingual web design and trust in e-government", International Journal of Electronic Government Research, 5 (1): 36-49.

Sergunin, Alexander, and Pertti Joenniemi, 2014. "Paradiplomacy as a sustainable development strategy: The case of Russia's Arctic subnational actors", Eurasia Border Review, 5 (2): 1-17.

Stremoukhov, Denis, 2021. "When governors go abroad: Incentives for paradiplomacy in recentralised Russia”, Regional \& Federal Studies: 1-25.

Surwandono and Ali Maksum, 2019. "The dynamics of paradiplomacy practices in the 'Frontier' areas in Indonesia", Journal of ASEAN Studies, 6 (2): 137-154.

Surwandono, S., and Ali Maksum, 2020. "The Architecture of Paradiplomacy Regime in Indonesia: A Content Analysis”, Global: Jurnal Politik Internasional, 22(1): 77-99.

Vieira de Jesus, Diego Santos, 2017. "The Art of Encounter: Paradiplomacy and Internationalization of Creative Cities", $R e-$ vista de Sociologia e Política, 25(61): 51-76.

Wiratmo, Liliek Budiastuti, et al., 2017. "Website Pemerintah Daerah Sebagai Sarana Online Public Relations”, Jurnal ASPIKOM, 3(2): 326-339.

Zeraoui, Zidane, and Fernando R. Castillo Villar, 2016. "The Paradiplomacy of the Cities. A Strategy of Urban Development”, Revista Del Clad Reforma Y Democracia, (65): 225-242. 


\section{Conference Paper}

Amalia, A., Gunawan, D., Lydia, M. S., \& Charlie, C.et al., (2017). "The usage evaluation of official computer terms in Bahasa Indonesia in Indonesian government official websites", in. IOP Conference Series: Materials Science and Engineering, 180(1). IOP Publishing.

Cyrill, Melissa M., and Aftab Kamal Pasha, 2019. "Diplomacy in the Internet Age-Challenges and Opportunities for the UAE", in Advances in Science, Technology and Innovation, pp. 85-93. Cham: Springer Nature.

Iamamphai, P., et al., 2016. "Investigations and comparisons of government open data websites through systematic functional analysis and efficient promotion approach," 2016 Management and Innovation Technology International Conference (MITicon), pp. MIT-142-MIT-147.

Keating, Michael, 2000. "Paradiplomacy and regional networking", in Forum of Federations: an International Federalism, October. Hanover.

Koffa, Antigoni, and Anastasia N. Kastania, 2010. "Web applications and public diplomacy", in International Conference on Knowledge-Based and Intelligent Information and Engineering Systems (pp. 53-62). Springer, Berlin, Heidelberg.

Stremoukhov, Denis, 2019. "When Governors Go Abroad: Factors of Paradiplomacy in Russia", Higher School of Economics Research Paper No. WP BRP, 66.

Wang, Fang, and Ying Wang, 2013. A Grounded Theory of Government Website Promotion. In European Conference on Digital Government (p. 551). Academic Conferences International Limited, June.

Yinqi, 2011. "Research on performance of the government website", in 3rd International Conference on Computer Research and Development, 11-13 March, Shanghai.

Yunita, Novi Prisma, and Rudi Dwi Aprianto, 2018. "Kondisi Terkini Perkembangan Pelaksanaan E-Government di Indonesia: Analisis Website", in Seminar Nasional Teknologi 
Evaluation on Indonesian's Local Government Website for Practicing Paradiplomacy

Informasi dan Komunikasi (pp. 329-336), 23-24 March. Yogyakarta: Fakultas Teknologi Industri Universitas Atma Jaya.

\section{Others}

Lecours, André, 2008. "Political Issues of Paradiplomacy", Discussion Papers in Diplomacy. Netherlands Institute of International Relations 'Clingendael'.

Putri, Arum S., 2020. "Jumlah Kabupaten dan Provinsi di Indonesia”, Kompas, 8 January [online]. in https://www.kompas. com/skola/read/2020/01/o8/150000469/jumlah-kabupaten-dan-provinsi-di-indonesia?page $=$ all $[$ accessed on 30 September 2021].

van der Pluijm, Rogier, 2007. "City Diplomacy: The Expanding Role of Cities in International Politics", in Clingendael Diplomacy Papers No. 10. The Hague: Clingendael. 
Surwandono, Ariyanto Nugroho, \& Muhammad Dedy Yanuar 